\title{
97
}

\section{Nonradioactive Methods for the Detection of RNA-Protein Interaction}

\author{
Asier Echarri, María Eugenia González, Iván Ventoso, and Luis Carrasco
}

\section{Introduction}

RNA in biological systems is associated with proteins. Recent work in eukaryotes has identified common motifs present in families of RNA-binding proteins. Usually, RNA-binding proteins recognize both sequence and structure at their target sites. Therefore, identification of proteins that interact with a specific RNA sequence contributes to the understanding of biological processes. Thus, the genome of human immunodeficiency virus (HIV) encodes proteins, Tat, Rev and NC, that bind to specific viral RNA motives $(1,2)$. These interactions mediate different steps of virus replication i.e., transactivation of transcription, nuclear export of viral transcripts, or packaging of two RNA genomes into the mature virion. In addition, we recently reported that Nef, an accessory protein encoded by HIV-1, belongs to the family of RNA-binding proteins (3). Using different-size variant proteins and point-mutated proteins, it was found that the amino terminal Arg-rich domain of Nef is involved in the RNA-binding activity. Nef proteins from HIV-2 and SIV (simian immunodeficiency virus) also showed RNA-binding capacity (4).

In this chapter we describe methodologies for the direct detection of RNA-protein interactions using biotinylated riboprobes. The northwestern assay involves the interaction of labeled RNA with proteins immobilized on a membrane support. This assay allows the identification of the specific protein present in a crude extract that interacts with a given RNA molecule. The UV crosslinking and gel retardation assays mimic the in vivo binding reaction in solution conditions using purified proteins and RNA molecules. Gel retardation assay separates RNA-protein complexes from free RNA in a gel matrix. This technique is very useful for dissociation kinetics and ionic strength analysis of the binding reaction. A UV crosslinking assay is particularly appropriate for detecting labile protein-nucleic acid complexes, because the UV irradiation fixes the complex in amounts sufficient for further analysis by sodium dodecyl sulfate/polyacrylamide gel electrophoresis (SDS-PAGE). All these techniques use biotinylated probes to detect RNA-protein complexes on blotted membranes. The advantages of these nonradioactive methods when compared to their radioactive counterparts are their safety, low cost, easy handling, and long-term storage of labeled riboprobes $(5,6)$.

From: The Nucleic Acid Protocols Handbook

Edited by: R. Rapley (c) Humana Press Inc., Totowa, NJ 


\section{Materials}

RNases are ubiquitous and heat stable; care should be taken to avoid nuclease contamination of either reagents and equipment. All solutions should be treated with diethylpyrocarbonate (DEPC), an inhibitor of RNases, or dissolved in DEPC-treated $\mathrm{dH}_{2} \mathrm{O}$ (see Note 1). Gloves should be worn.

\subsection{In Vitro Synthesis of Biotin-Labeled Riboprobes}

1. $5 \mu \mathrm{g}$ Linearized template DNA in RNase-free $\mathrm{dH}_{2} \mathrm{O}$.

2. $2.5 \mathrm{~m} M$ ATP, CTP, and GTP, $10 \mathrm{~m} M$ UTP (Amersham Pharmacia Biotech) and $10 \mathrm{~m} M$ biotin21-UTP (Clontech, Palo Alto, CA).

3. $40 \mathrm{U}$ T7 or SP6 RNA Polymerase, $50 \mathrm{U}$ RNasin ribonuclease inhibitor and RQ1 RNasefree DNase (Promega, Madison, WI).

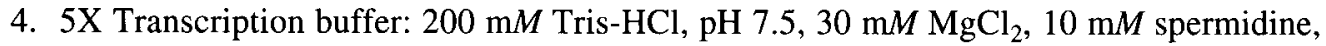
$50 \mathrm{~m} M \mathrm{NaCl}$.

5. $100 \mathrm{~m} M$ DL-dithiothreitol (DTT).

6. Sephadex G-50 column (Pharmacia).

7. DEPC-treated $\mathrm{dH}_{2} \mathrm{O}$ (see Note 1 ).

\subsection{Northwestern Assay}

1. $10 X$ Ponceau $\mathrm{S}: 2 \%(\mathrm{w} / \mathrm{v})$ ponceau $\mathrm{S}, 30 \%(\mathrm{v} / \mathrm{v})$ trichloroacetic acid, $30 \%(\mathrm{v} / \mathrm{v})$ sulfosalicylic acid.

2. Binding buffer: $10 \mathrm{~m} M$ Tris-HCl, pH 7.5, $1 \mathrm{~m} M$ EDTA, $50 \mathrm{~m} M \mathrm{NaCl}, 0.1 \%$ (v/v) Triton$\mathrm{X}-100,1 \mathrm{X}$ Denhardt's solution (50X: 1\% Ficoll (Pharmacia, Piscataway, NJ), $1 \%$ polyvinylpyrrolidone, and $1 \%$ bovine serum albumin [BSA]).

3. Transfer buffer: $50 \mathrm{~m} M$ Tris- $\mathrm{HCl}, \mathrm{pH} 8.3,380 \mathrm{~m} M$ glycine, and $20 \%(\mathrm{v} / \mathrm{v})$ methanol.

4. Streptavidin-peroxidase (POD) conjugate at $500 \mathrm{U} / \mathrm{mL}$ (Boehringer Mannheim, Mannheim, Germany).

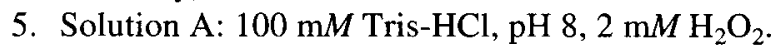

6. Solution B: $2.5 \mathrm{~m} M$ luminol, $75 \mu M$ D(-)luciferin (Boehringer Mannheim). Prepare a solution of $2.5 \mathrm{mM}$ luminol dissolved in $100 \mathrm{mM}$ Tris- $\mathrm{HCl}$, pH 8 , (store at $4^{\circ} \mathrm{C}$ in dark bottle), and a stock solution of $35 \mathrm{~m} M \mathrm{D}(-)$ luciferin dissolved in $100 \mathrm{mM}$ Tris- $\mathrm{HCl}$, pH 8 , (store in $25 \mu \mathrm{L}$ aliquots at $-70^{\circ} \mathrm{C}$ protected from light). To prepare solution $\mathrm{B}, \operatorname{mix} 10 \mathrm{~mL}$ $2.5 \mathrm{~m} M$ luminol and $22 \mu \mathrm{L} 35 \mathrm{~m} M \mathrm{D}(-)$ luciferin (see Note 4).

7. Nitrocellulose membrane (Bio-Rad, Hercules, CA).

8. SDS $15 \%(\mathrm{w} / \mathrm{v})$ polyacrylamide gel (7).

9. DEPC-treated $\mathrm{dH}_{2} \mathrm{O}$ (see Note 1 ).

\subsection{Gel Retardation Assay}

1. $100 \mathrm{~m} M$ sodium phosphate, $\mathrm{pH} \mathrm{7:} \mathrm{mix} 57.7 \mathrm{~mL}$ of $0.5 \mathrm{M} \mathrm{Na}_{2} \mathrm{HPO}_{4}$ with $42.3 \mathrm{~mL}$ $0.5 \mathrm{M} \mathrm{NaH}_{2} \mathrm{PO}_{4}$, add DEPC-treated $\mathrm{dH}_{2} \mathrm{O}$ to $500 \mathrm{~mL}$.

2. $99 \%$ Glycerol.

3. $250 \mathrm{~m} M$ HEPES, $\mathrm{pH} 7.5$.

4. $100 \mathrm{~m} M \mathrm{KCl}$.

5. $20 \mathrm{U}$ RNasin ribonuclease inhibitor.

6. $20 X$ SSC: $3 M \mathrm{NaCl}, 300 \mathrm{~m} M \mathrm{Na}_{2}$ Citrate $\cdot 2 \mathrm{H}_{2} \mathrm{O}$, Adjust $\mathrm{pH}$ to 7 with $\mathrm{HCl}$.

7. Nitrocellulose membrane.

8. Agarose (low melting point) dissolved in $10 \mathrm{~m} M$ sodium phosphate, $\mathrm{pH} 7$, at $1 \%(\mathrm{w} / \mathrm{v})$. To prepare $250 \mathrm{~mL}$ of agarose use a 1-L bottle and dissolve by heating in a microwave until the solution is completely clear. 
9. Paper towels.

10. Whatman 3MM paper (Whatman, Maidstone, Kent, UK).

11. BSA.

12. Phosphate-buffered saline (PBS): $137 \mathrm{mM} \mathrm{NaCl}, 2.7 \mathrm{mM} \mathrm{KCl}, 4.3 \mathrm{mM} \mathrm{Na} 2 \mathrm{HPO}_{4} \cdot 7 \mathrm{H}_{2} \mathrm{O}$, $1.4 \mathrm{mM} \mathrm{KH}_{2} \mathrm{PO}_{4}$.

13. Buffer P: PBS plus $0.05 \%(\mathrm{v} / \mathrm{v})$ Tween 20 .

14. Streptavidin-POD conjugate at $500 \mathrm{U} / \mathrm{mL}$.

15. Solution A and B (see Subheading 2.2., steps 5 and 6).

16. Vacuum oven.

17. Loading buffer ( $0.25 \%$ bromophenol blue, $0.25 \%$ xylene cyanol FF, $30 \%$ glycerol).

18. DEPC-treated $\mathrm{dH}_{2} \mathrm{O}$ (see Note 1).

\subsection{UV Crosslinking}

1. UV lamp with $254 \mathrm{~nm}$ wavelength.

2. 96 Microwell plate.

3. $250 \mathrm{~m} M$ HEPES, $\mathrm{pH} 7.5$.

4. $100 \mathrm{mM} \mathrm{KCl}$.

5. Streptavidin-POD conjugate at $500 \mathrm{U} / \mathrm{mL}$.

6. Solution A and B (see Subheading 2.2., steps 5 and 6).

7. RNase $A$ at $1.5 \mu \mathrm{g} / \mu \mathrm{L}$.

8. 5X Buffer sample: $29.2 \mathrm{~mL} 1 \mathrm{M}$ Tris- $\mathrm{HCl}, \mathrm{pH} 6.8,22 \mathrm{~mL} 99 \%$ glycerol, $8.3 \mathrm{~g}$ sodium dodecyl sulfate (SDS), $7.75 \mathrm{~g}$ DTT, $50 \mathrm{mg}$ bromophenol blue, to $100 \mathrm{~mL}$ with $\mathrm{dH}_{2} \mathrm{O}$.

9. SDS $15 \%(\mathrm{w} / \mathrm{v})$ polyacrylamide gel (7).

10. Buffer P: PBS plus $0.05 \%(\mathrm{v} / \mathrm{v})$ Tween 20.

11. Transfer buffer (see Subheading 2.2., step 3).

12. DEPC-treated $\mathrm{dH}_{2} \mathrm{O}$ (see Note 1).

\section{Methods}

\subsection{In Vitro Synthesis of Biotin-Labeled Riboprobes}

Time required: see Note 3.

1. Add the following components at room temperature in the order listed:

$\begin{array}{ll}5 X \text { Transcription buffer } & 20 \mu \mathrm{L} \\ 100 \mathrm{~m} M \text { DTT } & 10 \mu \mathrm{L} \\ \text { RNasin ribonuclease inhibitor } & 50 \mathrm{U} \\ 2.5 \mathrm{~m} M \text { GTP, ATP, and CTP } & 20 \mu \mathrm{L} \\ 10 \mathrm{~m} M \text { UTP } & 2.5 \mu \mathrm{L} \\ 10 \mathrm{~m} M \text { biotin-21-UTP } & 2.5 \mu \mathrm{L} \\ 5 \mu \mathrm{g} \text { Linearized template DNA } & \\ \text { T7 or SP6 RNA polymerase } & 20 \mathrm{U} \\ \text { DEPC-treated } \mathrm{dH}_{2} \mathrm{O} & \text { to } 100 \mu \mathrm{L}\end{array}$

2. Mix and incubate for $45 \mathrm{~min}$ at $37^{\circ} \mathrm{C}$.

3. Add again $20 \mathrm{U}$ of $\mathrm{T} 7$ or SP6 RNA polymerase and incubate for a further $45 \mathrm{~min}$ at $37^{\circ} \mathrm{C}$.

4. Add $1 \mathrm{U}$ RQ1 RNase-free DNase per $\mu \mathrm{g}$ of template DNA. Incubate $30 \mathrm{~min}$ at $37^{\circ} \mathrm{C}$.

5. The unincorporated nucleotides are eliminated from the reaction mixture by chromatography on a Sephadex G-50 column (see Notes 2 and 11).

6. Determine riboprobe concentration by measuring optical density at a wavelength of $260 \mathrm{~nm}$. Concentration should be between $100-500 \mathrm{ng} / \mu \mathrm{L}$ (see Note 9). 
A

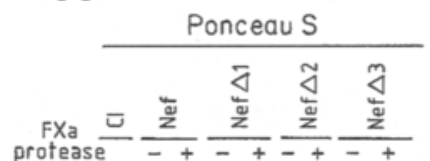

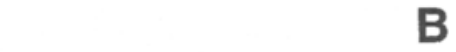

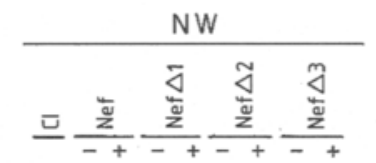

$\frac{\mathrm{KOa}}{6 \mathrm{~s}}$

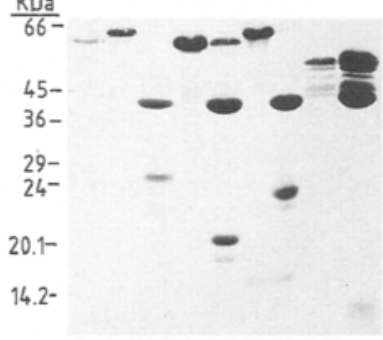

B

Gel retardation

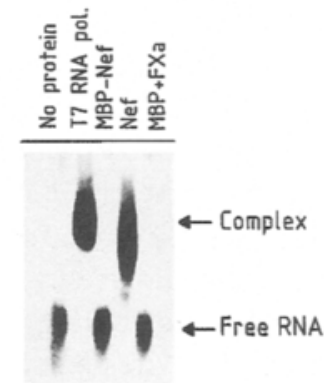

Fig. 1. A. Northwestern assay of HIV-1 nef proteins with biotinylated riboprobe. The left panel shows ponceau $S$ staining of different proteins separated by SDS-PAGE and transferred to nitrocellulose membrane. After renaturation of the proteins in binding buffer, the membrane was incubated with $600 \mathrm{ng}$ of biotinylated riboprobe (7830-8932 nucleotides of BH10 HIV-1 RNA), with streptavidin-POD peroxidase and then with detection solution. An autoradiography ( 2 min exposure) is shown in the right panel (NW). Potyvirus CI protein was used as a positive control. All proteins (except $\mathrm{CI}$ ) were purified as fusion constructs with maltose binding protein (MBP, $41 \mathrm{KDa}$ ). MBP was separated from different nef proteins by Factor Xa protease digestion $(+)$ or not $(-)$. Nef (from HIV-1 bru) is the wild-type protein (27 KDa); nef $\Delta 1$ lacks 33 amino acids from the carboxy terminus $(20 \mathrm{KDa})$, nef $\Delta 2$ lacks 22 amino acids from the amino terminus ( $23 \mathrm{KDa}$ ), and nef $\Delta 3$ lacks 104 amino acids from the carboxy terminus $(13 \mathrm{KDa})$. B. Gel retardation assay with biotinylated riboprobe. Fifty nanograms of biotinylated riboprobe (7830-8932 nucleotides of BH10 HIV-1 RNA) were incubated with different proteins, loaded on the agarose gel, transferred by capillary action to nitrocellulose membrane, and incubated with detection solution. Autoradiography ( 1 min exposure) shows the biotinylated-free RNA or RNA-protein complexes. MBP-nef, nef, T7 RNA polymerase (positive control) and MBP + Factor Xa protease were tested for their ability to bind RNA; only nef and T7 RNA polymerase form complexes with RNA.

\subsection{Northwestern Assay}

Time required: see Note 3 .

1. Protein samples $(0.5-5 \mu \mathrm{g})$ are diluted $1: 1$ in $2 \mathrm{X}$ buffer sample (see Note 7 ) and run in a standard SDS-15\% PAGE at $30 \mathrm{~mA}$ (see Note 8). Do not boil protein samples.

2. The gel is transferred to a nitrocellulose filter in transfer buffer at $200 \mathrm{~mA}$ for $16 \mathrm{~h}$ (see Note 10) (8).

3. Stain the filter with ponceau S (see Fig. 1A, left panel) and mark the position of molecular weight marker with a glasswriter (see Note 12).

4. For renaturation of the proteins incubate the nitrocellulose filter in a RNase-free tray (see Note 1.2) containing binding buffer at room temperature with agitation on a platform shaker for $2 \mathrm{~h}$ (change binding buffer every $30 \mathrm{~min}$ ).

5. Incubate the renatured proteins with the riboprobe at $20-50 \mathrm{ng}$ riboprobe/ml binding buffer (usually $1-5 \mu \mathrm{L}$ of transcription reaction in $10 \mathrm{~mL}$ of binding buffer) at room temperature for $1 \mathrm{~h}$. 
6. Wash the filter three times ( 2 min each) with binding buffer to remove the unbound riboprobe.

7. Incubate with streptavidin-POD conjugate, diluted 1:20,000 in binding buffer, for $30 \mathrm{~min}$. Cover the dish with aluminum paper until step 10.

8. Wash three times ( 2 min each) with binding buffer.

9. Incubate for $1 \mathrm{~min}$ in detection solution (mix $10 \mathrm{~mL}$ of freshly made solution $\mathrm{A}$ with $10 \mathrm{~mL}$ of freshly made solution B; see Subheading 2.2., steps 5 and 6).

10. Air dry the filter, cover with a plastic sheet, and expose to X-ray films (Fig. 1A, right panel), usually for $30 \mathrm{~s}$ to $10 \mathrm{~min}$ (see Note 5).

\subsection{Gel Retardation Assay}

Time required: see Note 3 .

1. Decontaminate all plasticware with $\mathrm{H}_{2} \mathrm{O}_{2}$ (see Note 1.b.).

2. Prepare $1 \%(\mathrm{w} / \mathrm{v})$ agarose gel of appropriate length (approx $15 \mathrm{~cm}$ ) and depth (approx $8 \mathrm{~mm}$ ) and let solidify at $4^{\circ} \mathrm{C}$. Use $10 \mathrm{~m} M$ sodium phosphate, $\mathrm{pH} 7$, as electrophoresis buffer and prerun the agarose gel for $15 \mathrm{~min}$ at $4^{\circ} \mathrm{C}$ at $20 \mathrm{~V}(9)$.

3. Set up binding reaction in a microcentrifuge tube:

$\begin{array}{ll}250 \mathrm{~m} M \text { HEPES, } \mathrm{pH} 7.5 & 1.6 \mu \mathrm{L} \\ 100 \mathrm{~m} M \mathrm{KCl} & 2 \mu \mathrm{L} \\ \text { Biotinylated RNA } & 20-200 \mathrm{ng} \\ \text { RNasin ribonuclease inhibitor } & 20 \mathrm{U} \\ \text { Purified protein } & 0.5-2 \mu \mathrm{g}(<5 \mu \mathrm{L}) \\ \text { DEPC treated } \mathrm{dH}_{2} \mathrm{O} & \text { to } 20 \mu \mathrm{L}\end{array}$

4. Mix and incubate at room temperature for $15 \mathrm{~min}$.

5. Add $2.2 \mu \mathrm{L} 99 \%$ glycerol to the reaction mixtures and load the samples. Load in an adjacent lane $5 \mu \mathrm{L}$ of loading buffer. Run at $20 \mathrm{~V}$ for $16 \mathrm{~h}$ or until the bromophenol blue has migrated $80 \%$ of the gel length, at $4^{\circ} \mathrm{C}$.

6. Incubate the agarose gel in $20 \mathrm{X}$ saline sodium citrate (SSC) for $1 \mathrm{~h}$ with agitation at room temperature.

7. Meanwhile, cut a piece of nitrocellulose filter to the gel size. Wet with $\mathrm{dH}_{2} \mathrm{O}$ and soak in 20X SSC for $30 \mathrm{~min}$.

8. Transfer the gel to the filter by capillary action (10) as follows. Place a piece of Whatman $3 \mathrm{MM}$ paper wetted with 20X SSC on a piece of glass to form a support that is longer and wider than the agarose gel. Place the support inside a large baking dish. Fill the dish with 20X SSC. Immerse the Whatman 3MM paper edges into the 20X SSC. Place the gel on the support, avoiding air bubbles. Surround the gel with Saran Wrap. Place the wet nitrocellulose membrane on top of the gel, avoiding air bubbles (mark position of the wells on the nitrocellulose membrane with a pencil or glasswriter). Place on top of nitrocellulose, in the order listed, four pieces of Whatman 3MM paper, $10 \mathrm{~cm}$ of paper towels, a glass plate, and a 500-g weight. Allow overnight capillary transfer.

9. Dry the nitrocellulose by baking for $2 \mathrm{~h}$ at $80^{\circ} \mathrm{C}$ in a vacuum oven.

10. Incubate the nitrocellulose filter in buffer P plus $3 \%(\mathrm{w} / \mathrm{v}) \mathrm{BSA}$ for $30 \mathrm{~min}$.

11. Wash once with buffer $P$ for 1 min.

12. Incubate with streptavidin-POD conjugate dissolved $1: 20,000$ in buffer $P$ for $30 \mathrm{~min}$. Cover the dish with aluminum foil until step 15.

13. Wash with buffer $P$ for $10 \mathrm{~min}$. Repeat this step twice.

14. Incubate for $1 \mathrm{~min}$ in detection solution (mix $10 \mathrm{~mL}$ of freshly made solution A with $10 \mathrm{~mL}$ of freshly made solution B; see Subheading 2.2., steps 5 and 6).

15. Air dry in the dark, cover with plastic sheet, and expose the filter to X-ray films for 30-300 s (see Fig. 1B and Note 5). 


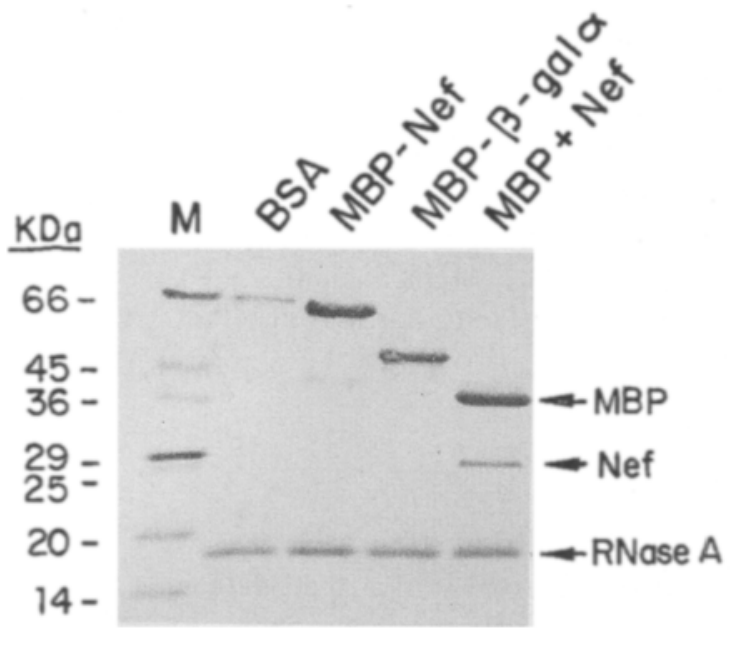

Ponceau S

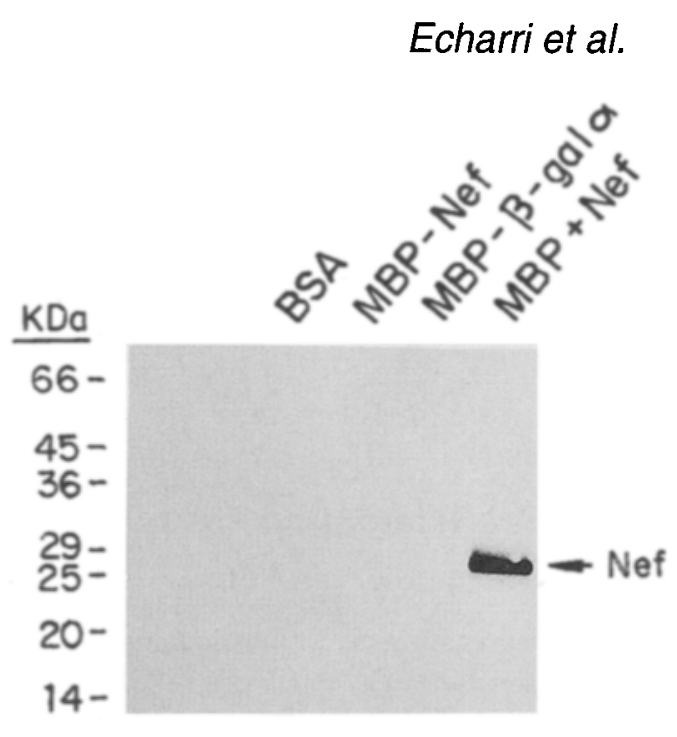

Autoradiography

Fig. 2. UV crosslinking assay of HIV-1 nef protein using biotinylated riboprobe. Ponceau S staining (left panel) of the nitrocellulose membrane and autoradiography (right panel) of the membrane after treatment with detection solution. Eight hundred nanograms of biotinylated RNA (1-829 nucleotides of BH10 HIV-1) were used in each reaction. Autoradiography (3 min exposure) is shown. Only free nef protein interacts with RNA.

\subsection{UV Crosslinking Assay}

Time required: see Note 3.

1. Set up binding reaction in a microcentrifuge tube (see Note 7):

$\begin{array}{ll}250 \mathrm{~m} M \text { HEPES, pH } 7.5 & 1.6 \mu \mathrm{L} \\ 100 \mathrm{~m} M \mathrm{KCl} & 2 \mu \mathrm{L} \\ \text { Biotinylated RNA } & 300-1500 \mathrm{ng} \\ \text { Purified protein } & 0.5-2 \mu \mathrm{g}(<5 \mu \mathrm{L}) \\ \text { DEPC-treated } \mathrm{dH}_{2} \mathrm{O} & \text { to } 20 \mu \mathrm{L}\end{array}$

2. Mix and incubate at room temperature for $15 \mathrm{~min}$.

3. Transfer the reaction to a 96-microwell plate and place the plate on ice during exposure to UV. Irradiate the reaction mixture for $10 \mathrm{~min}$ at $4^{\circ} \mathrm{C}$ using a $254-\mathrm{nm}$ UV lamp placed $4 \mathrm{~cm}$ above the samples. Protect from irradiation outside the sample by covering the lamp with aluminum foil during this step (see Note 6).

4. Add to the reaction $1 \mu \mathrm{L}$ of $1.5 \mu \mathrm{g} / \mu \mathrm{L}$ RNase $\mathrm{A}$ and incubate for $30 \mathrm{~min}$ at $37^{\circ} \mathrm{C}$.

5. Add $5 \mu \mathrm{L} 5 \mathrm{X}$ buffer sample and separate proteins by SDS-15\% PAGE at $30 \mathrm{~mA}$.

6. Transfer the gel to a nitrocellulose membrane at $200 \mathrm{~mA}$ in transfer buffer overnight.

7. Stain the proteins with IX ponceau S (Fig. 2, left panel). Mark molecular weight standards on the nitrocellulose filter with a glasswriter (see Note 12).

8. Incubate the filter in buffer P plus $3 \%(\mathrm{w} / \mathrm{v}) \mathrm{BSA}$ for $30 \mathrm{~min}$.

9. Wash once with buffer $P$ for 1 min.

10. Incubate with streptavidin-POD conjugate dissolved 1:40,000 in buffer $\mathrm{P}$ for $30 \mathrm{~min}$. Cover the dish with aluminum foil until the last step.

11. Follow Subheading 3.3., steps 13-15 (Fig. 2, right panel). 


\section{Notes}

1. DEPC reacts rapidly with amines and cannot be used to treat solutions containing buffers such as Tris. DEPC can modify purine residues in RNA by carboxymethylation. DEPC is suspected to be a carcinogen.

a. DEPC treatment: Add the DEPC to $\mathrm{dH}_{2} \mathrm{O}$ or to the indicated solution to a concentration of $0.1 \%(\mathrm{v} / \mathrm{v})$. Mix well and allow to stand overnight in a fumehood. Autoclave the liquids to eliminate the DEPC.

b. Preparation of RNase-free plasticware: Wash the electrophoresis tanks, combs, and casting trays with $3 \%(\mathrm{v} / \mathrm{v}) \mathrm{H}_{2} \mathrm{O}_{2}$ for $1 \mathrm{~h}$ and rinse with DEPC-treated $\mathrm{dH}_{2} \mathrm{O}$.

2. Do not use phenol extraction, as biotinylated probes are soluble in the phenol layer.

3. Duration of procedures:

a. In vitro synthesis of biotin labeled riboprobe: $1 \mathrm{~d}$

Transcription

DNA digestion

Chromatography

b. Northwestern assay: $2 \mathrm{~d}$

SDS-PAGE $(10 \times 10 \mathrm{~cm})$

Transfer

Renaturation and detection of RNA

c. Gel retardation assay: $3 \mathrm{~d}$

Gel preparation:

Running the samples:

Transfer

Detection of RNA

d. UV crosslinking assay: $2 \mathrm{~d}$

Reaction, UV light and RNA digestion

Running the gel

Transfer

Detection of RNA
$1.5 \mathrm{~h}$

$30 \mathrm{~min}$

$15 \mathrm{~min}$

$3 \mathrm{~h}$

overnight

$4 \mathrm{~h}$

$4 \mathrm{~h}$

overnight

$1.5 \mathrm{~h}+$ overnight

$4 \mathrm{~h}$

$1.5 \mathrm{~h}$

$3 \mathrm{~h}$

overnight

$2 \mathrm{~h}$

4. D(-)Luciferin solution sometimes does not become completely clear but works well nonetheless.

5. Usually $1 \mathrm{~min}$ exposure is enough to detect biotinylated RNA. Exposition can be extended for $3 \mathrm{~h}$. However if the signal is strong, long exposures could decrease the band intensity.

6. Longer periods of irradiation will not improve the signal intensity. Protein degradation and/or oligomerization may occur if longer periods of irradiation are used.

7. Streptavidin-POD conjugate can interact with some proteins such as RNase A. Moreover, some proteins, such as propionyl-CoA carboxylase and pyruvate carboxylase, can interact with biotin. In the case of Northwestern and UV crosslinking assays, a negative control without biotinylated riboprobe is recommended.

8. Electrical currents greater than $30 \mathrm{~mA}$ can cause irreversible denaturation of the protein. A $10 \times 10 \mathrm{~cm}$ SDS-PAGE at $30 \mathrm{~mA}$ requires $3 \mathrm{~h}$ electrophoresis.

9. Biotinylated transcripts can be quantified by serial dilution of $1 \mu \mathrm{L}$ transcription reaction in 20X SSC spotted to nitrocellulose with a dot-blot apparatus (Bio-Rad). Filters are dried at $80^{\circ} \mathrm{C}$ for $2 \mathrm{~h}$ in vacuo and the biotinylated riboprobes are detected as in Subheading 3.3., steps 10-15 is described.

10. Protein transfer from the gel to the nitrocellulose filter is performed wet, because semidry transfer causes heating of the samples and may inhibit subsequent renaturation of the transferred proteins (11).

11. Alternatively, ethanol precipitation can be performed. 
12. Ponceau $S$ staining fades after renaturation and treatment of the nitrocellulose membrane with detection solution.

13. Potential problems:

a. In vitro synthesis of biotin labeled riboprobes:

i. Low amounts of riboprobe: Make sure that reaction components are at room temperature. Add larger amount of linearized plasmid dissolved in $\mathrm{RNase}$ free $\mathrm{dH}_{2} \mathrm{O}$ to the reaction mixture and make sure that no $\mathrm{NaCl}$ is present in the template solution ( $\mathrm{NaCl}$ concentration higher than $30 \mathrm{~m} M$ could inhibit RNA polymerase activity). Make sure that all solutions are RNase free.

ii. Presence of transcripts longer than expected: DNA template should be completely digested with an enzyme that generates a protruding 5 ' terminus. If it is impossible to use such a restriction enzyme, the linear DNA template should be "blunt ended."

b. Northwestern assay: If the riboprobe is correct, the problems could be:

i. The positive control does not bind RNA: Solutions and/or labware contaminated with RNase is a possible cause. Treat all the solutions with DEPC and the plasticware with $3 \%(\mathrm{v} / \mathrm{v}) \mathrm{H}_{2} \mathrm{O}_{2}$. Check that luminol, luciferin, and $\mathrm{H}_{2} \mathrm{O}_{2}$ are at a correct concentration and stored in the dark.

ii. A nonspecific background signal is obtained: Reduce the riboprobe concentration or increase the duration of the washes.

c. Gel retardation assay:

i. Biotinylated RNA cannot be visualized: Incorrect transfer. Use a heavier weight for the transfer. The paper towels perhaps may not have been in contact with the transfer buffer.

ii. Spots in autoradiography: Air bubbles between nitrocellulose and the agarose gel were present.

d. UV crosslinking assay:

i. The proteins disappear: Check the transfer buffer and current during the transfer procedure. There is excess UV light irradiation.

ii. Band smearing: Incomplete RNase A digestion.

iii. Low band intensity: Concentrate the riboprobe by ethanol precipitation to $1 \mu \mathrm{g} / \mu \mathrm{L}$.

\section{Acknowledgments}

The expert technical assistance of Mr. M. A. Sanz is acknowledged. The authors thank J. A. García and A. Fernández for kindly giving us CI protein. DGICYT project number PB94-0148 and the institutional grant to the CBM of Fundación Ramón Areces are acknowledged for their financial support. A. E. is a holder of a Gobierno Vasco fellowship and I. V. is a holder of a Comunidad Autónoma de Madrid fellowship.

\section{References}

1. Luban, J. and Goff, S. P. (1991) Binding of human immunodeficiency virus type 1 (HIV-1) RNA to recombinant HIV-1 gag polyprotein. J. Virol. 65, 3203-3212.

2. Mattaj, I. W. (1990) A selective review of RNA-protein interactions in eukaryotes. Mol. Biol. Rep. 14, 151-155.

3. Echarri, A., González, M. E., and Carrasco, L. (1996) Human immunodeficiency virus (HIV) nef is an RNA binding protein in cell-free systems. J. Mol. Biol. 262, 640-651.

4. Echarri, A., González, M. E., and Carrasco, L. (1997) The N-Arg-rich region of human immunodeficiency virus types 1 and 2 and simian immunodeficiency virus Nef is involved in RNA binding. Eur. J. Biochem. 246, 38-44. 
5. Rodríguez, P. L. and Carrasco, L. (1996) Biotin labeled riboprobes to study RNA-binding proteins, in A Laboratory Guide to Biotin-Labeling in Biomolecule Analysis (Meier, T. and Fahrenholz, F., eds.) Birkhäuser Verlag, Basel, Switzerland, 215-225.

6. Rodríguez, P. L. and Carrasco, L. (1994) Nonradioactive northwestern analysis using biotinylated riboprobes. Biotechniques 17, 702-705.

7. Sambrook, J., Fritsch, E. R., and Maniatis, T., eds. (1989) Molecular Cloning: A Laboratory Manual, 2nd ed. Cold Spring Harbor Laboratory Press, Cold Spring Harbor, NY.

8. Harlow, E. and Lane, D. (1988) Antibodies. A Laboratory Manual, Cold Spring Harbor Laboratory Press, Cold Spring Harbor, NY.

9. Lin, J. H., Chang, M. F., Baker, S. C., Govindarajan, S., and Lai, M. M. C. (1990) Characterization of hepatitis delta antigen: Specific binding to hepatitis delta virus RNA. J. Virol. 64, 4051-4058.

10. Southern, E. M. (1975) Detection of specific sequences among DNA fragments separated by gel electrophoresis. J. Mol. Biol. 98, 503-517.

11. Chen, X., Sadlock, J., and Schon, E. A. (1993) RNA-binding patterns in total human tissue proteins: Analysis by Northwestern blotting. Biochem. Biophys. Res. Commun. 191, 18-25. 